Article

\title{
Production of Chitin from Penaeus vannamei By-Products to Pilot Plant Scale Using a Combination of Enzymatic and Chemical Processes and Subsequent Optimization of the Chemical Production of Chitosan by Response Surface Methodology
}

\author{
José A. Vázquez ${ }^{1, *}$, Patrícia Ramos ${ }^{2}$, Jesús Mirón ${ }^{1}$, Jesus Valcarcel ${ }^{1,2}$, Carmen G. Sotelo ${ }^{2}$ and \\ Ricardo I. Pérez-Martín ${ }^{2}$ \\ 1 Grupo de Reciclado y Valorización de Materiales Residuales (REVAL), Instituto de Investigacións \\ Mariñas (IIM-CSIC) r/Eduardo Cabello, 6, Vigo 36208, Galicia, Spain; \\ suso@iim.csic.es (J.M.); jvalcarcel@iim.csic.es (J.V.) \\ 2 Grupo de Bioquímica de Alimentos, Instituto de Investigacións Mariñas (IIM-CSIC) r/Eduardo Cabello, 6, \\ Vigo 36208, Galicia, Spain; ariza@iim.csic.es (P.R.); carmen@iim.csic.es (C.G.S.); ricardo@iim.csic.es (R.I.P.-M.) \\ * Correspondence: jvazquez@iim.csic.es; Tel.: +34-986-231-930; Fax: +34-986-292-762
}

Received: 12 May 2017; Accepted: 9 June 2017; Published: 16 June 2017

\begin{abstract}
The waste generated from shrimp processing contains valuable materials such as protein, carotenoids, and chitin. The present study describes a process at pilot plant scale to recover chitin from the cephalothorax of Penaeus vannamei using mild conditions. The application of a sequential enzymatic-acid-alkaline treatment yields $30 \%$ chitin of comparable purity to commercial sources. Effluents from the process are rich in protein and astaxanthin, and represent inputs for further by-product recovery. As a last step, chitin is deacetylated to produce chitosan; the optimal conditions are established by applying a response surface methodology (RSM). Under these conditions, deacetylation reaches $92 \%$ as determined by Proton Nuclear Magnetic Resonance $\left({ }^{1} \mathrm{H}-\mathrm{NMR}\right)$, and the molecular weight $(\mathrm{Mw})$ of chitosan is estimated at $82 \mathrm{KDa}$ by gel permeation chromatography (GPC). Chitin and chitosan microstructures are characterized by Scanning Electron Microscopy (SEM).
\end{abstract}

Keywords: chitin; chitosan; Penaeus vannamei shells; response surface methodology; by-products valorization

\section{Introduction}

Prawns and shrimp are the second fish product marketed at world level, and constitute $8 \%$ of the total value of internationally traded fish products. In aquaculture, Penaeus vannamei is the top cultured species. Because of its great commercial value, the food industry processes a significant amount of these crustaceans, in many cases involving the removal of the exoskeleton of the tail and the cephalothorax. As a result, about $40-45 \%$ of the whole animal is considered by-products. This low yield combined with the commercial importance of this species results in high amounts of waste generated by its industrial processing. Therefore, alternatives for the treatment of these by-products are necessary, ideally scaled at pilot plant level to assess their viability.

The by-products generated contain compounds of interest, such as protein, pigments, and chitin. In particular, the exoskeleton represents the main source of chitin and chitosan [1]. The former is the second most abundant natural biopolymer after cellulose, and is one of the major sources of surface pollution in coastal areas. The biosynthesis of chitin involves the linkage of $\mathrm{N}$-acetylglucosamine 
units by $\beta-(1 \rightarrow 4)$ glycosidic bonds to form a long-chain polymer. The arrangement of chitin chains in crustacean shells is antiparallel ( $\alpha$-chitin) with strong intra- and inter-molecular forces. This structure makes chitin insoluble in most solvents, but can be increased by partial $\mathrm{N}$-deacetylation via an alkaline treatment to yield chitosan.

Chitin and its cationic derivative chitosan display functional and physicochemical properties that offer a wide range of industrial applications, and potentially solve numerous problems in the environmental, agricultural, cosmetic, and biomedical fields [2-5]. In particular, the food applications of chitin and chitosan are numerous, and include food preservation against microbial deterioration due to its antimicrobial activity; the formation of biodegradable films; and the clarification and deacidification of fruit juices, etc. [6]. In fish, chitosan coatings display preservative properties in herring and cod, reducing moisture loss, lipid oxidation, and microbial growth $[7,8]$.

Protocols for the purification of chitin from the endoskeletons and exoskeletons of crabs, squid, shrimp, etc., usually include steps of deproteinization, demineralization, and, in some cases, bleaching $[9,10]$. Secondary products such as extract hydrolysates and carotenoids can also be recovered from the residual effluents generated [11-13]. The subsequent reaction of deacetylation to transform chitin into chitosan is commonly mediated by alkaline treatments at temperatures higher than $100{ }^{\circ} \mathrm{C}$ [14-17]. Conventional methods for chitin and chitosan production are energy intensive, and require hazardous chemical compounds $[18,19]$. Safer and more environmentally friendly alternatives, based on the combination of microbial, enzymatic, and chemical strategies, have recently been reported [20-23]; but to date, the only studies about chitin purification at pilot plant or industrial scale are patents. Concise reports on the optimization of chitosan production from P. vannamei materials are practically nonexistent [24]. In this context, response surface methodology (RSM) is one of the most effective mathematical tools in order to evaluate the joint effect of several independent variables, and to maximize or minimize the production of the dependent variable object of study [25-27].

This work aims to provide a detailed report on the production of chitin from industrial by-products of $P$. vannamei at pilot plant scale, and the optimization of chitosan transformation from the chitin previously extracted. A combination of enzymatic-acid-alkaline treatments is developed for the purification of chitin, taking advantage of recent progress in deproteinization strategies with proteases. Short processing times, low temperature, and reduced alkali and acid concentrations complete the sequence to achieve a more sustainable process. In this same line, optimal conditions for chitosan production are established, based on response surface methodology. In all cases, the composition and physicochemical characteristics of the substrates and products are evaluated to ascertain their purity and quality.

\section{Results and Discussion}

\subsection{Pilot Plan Production of Chitin}

The moisture, ash, protein, and lipid contents of shrimp by-products were $76 \%, 4.76 \%, 55 \%$ and $1.6 \%$ respectively (Table 1 ). The compositional values are similar to the samples described in previous reports $[28,29]$. The process applied in the present work for the industrial production of chitin (Figure 1) is an improved modification of the alkaline-enzymatic methods reported by other authors [28,30-32]. These improvements are based on the reduction of the concentrations of alkaline $(1 \mathrm{M} \mathrm{NaOH})$ and acid reagents $(0.4 \mathrm{M} \mathrm{HCl})$, time ( $6 \mathrm{~h}$ for the whole process), and processing temperature (less than $65^{\circ} \mathrm{C}$ ), when compared to the more extreme conditions described in the cited works. The chitin thus obtained presents similar purity levels in terms of the ash content, the degree of acetylation, and the infrared fingerprint, which demonstrates that milder conditions are sufficient to obtain high quality chitin (Table 1). 
Table 1. Proximate composition of P. vanamei by-products and chitin extracted.

\begin{tabular}{ccc}
\hline \multicolumn{2}{c}{ Proximate Composition } & Content \\
\hline \multirow{3}{*}{ Raw material } & Ash & $76.0 \pm 0.06 \%$ dry base \\
& Protein & $45.76 \pm 0.80 \%$ dry base \\
Lipids & $1.6 \pm 0.2 \%$ dry base \\
\hline Ash & $1.44 \pm 0.07 \%$ dry base \\
& Nitrogen & $6.49 \pm 0.03 \%$ dry base \\
Lipids & $0.16 \pm 0.03 \%$ dry base \\
C/N & 6.69 \\
$\mathrm{DA}$ & $96.0 \%$ dry base \\
$\mathrm{Zn}$ & $21.36 \mathrm{ppm}$ \\
$\mathrm{Na}$ & $883.2 \mathrm{ppm}$ \\
$\mathrm{K}$ & $132.9 \mathrm{ppm}$ \\
$\mathrm{Mn}$ & $80.72 \mathrm{ppm}$ \\
$\mathrm{Mg}$ & $192.3 \mathrm{ppm}$ \\
$\mathrm{P}$ & $1023.3 \mathrm{ppm}$ \\
$\mathrm{Ca}$ & $2892 \mathrm{ppm}$ \\
$\mathrm{Sc}$ & $21.3 \mathrm{ppm}$ \\
$\mathrm{Se}$ & $0.24 \mathrm{ppm}$ \\
$\mathrm{Cu}$ & $2.37 \mathrm{ppm}$ \\
$\mathrm{Fe}$ & $33.24 \mathrm{ppm}$ \\
$\mathrm{Hg}$ & $0.12 \mathrm{ppm}$ \\
$\mathrm{Cd}$ & $0.31 \mathrm{ppm}$ \\
$\mathrm{Pb}$ & $1.13 \mathrm{ppm}$ \\
\hline
\end{tabular}

DA: is the degree of acetylation; $\mathrm{C} / \mathrm{N}$ : is the ratio carbon/nitrogen.

The degree of $N$-acetylation can be derived from the carbon/nitrogen ratio $(C / N)$, which is a fundamental parameter for discriminating between chitin and chitosan. Theoretically, that ratio is 6.9 for fully acetylated chitin, and 5.1 for fully deacetylated chitosan. The degree of acetylation $(D A)$ was calculated by the following equation [33]:

$$
D A(\%)=\frac{(C / N-5.14) \times 100}{1.72} .
$$

It resulted in a $D A$ of $96 \%$, and $C / N=6.69$ (Table 1) for the dry solids obtained at the end of the process line, which confirms its identity as chitin.

Figure 2 shows the comparison of the infrared spectra (IR) of the final product obtained from commercial chitin (A), and P. vannamei by-products (B). The identification of the characteristic chitin bands $\mathrm{OH}$ group at 3440-3447 $\mathrm{cm}^{-1}$; NH group at 3265-3266 $\mathrm{cm}^{-1}$; the $\mathrm{CH}$ band at $2927-2933 \mathrm{~cm}^{-1}$; and the amide I band at $1630 \mathrm{~cm}^{-1}[5,34]$, as well as the similar pattern, confirms chitin presence in the final product, in agreement with the DA results. In addition, the ash percentage was low $(1.44 \%)$, which reveals an almost complete demineralization of the sample under the conditions used in the process, and is consistent with the IR spectrum, free from interfering bands.

The scanning electron microscope (SEM) image of chitin displays the conventional surface with irregular shapes and heterogeneous size, observing asymmetric particles or microfibrils (Figure 3A) [35]. The linear sequence of $N$-acetylglucosamine monomers linked by covalent $\beta-(1 \rightarrow 4)$ glycosidic bonds is considered the primary structure of chitin. These chains are joined together by multiple hydrogen bonds in three-dimensional microfibrils, which constitutes their secondary structure. Moreover, microfibrils bind to proteins, and create the tertiary structure of chitin. The percentage of crystalline material in chitin (crystallinity index, ICr), calculated according to Segal et al. [36], is $88.1 \pm 3.7 \%$. The white flakes of chitin produced at the pilot plant are depicted in Figure 3B. The final yield of chitin recovery reaches $30 \%$. 

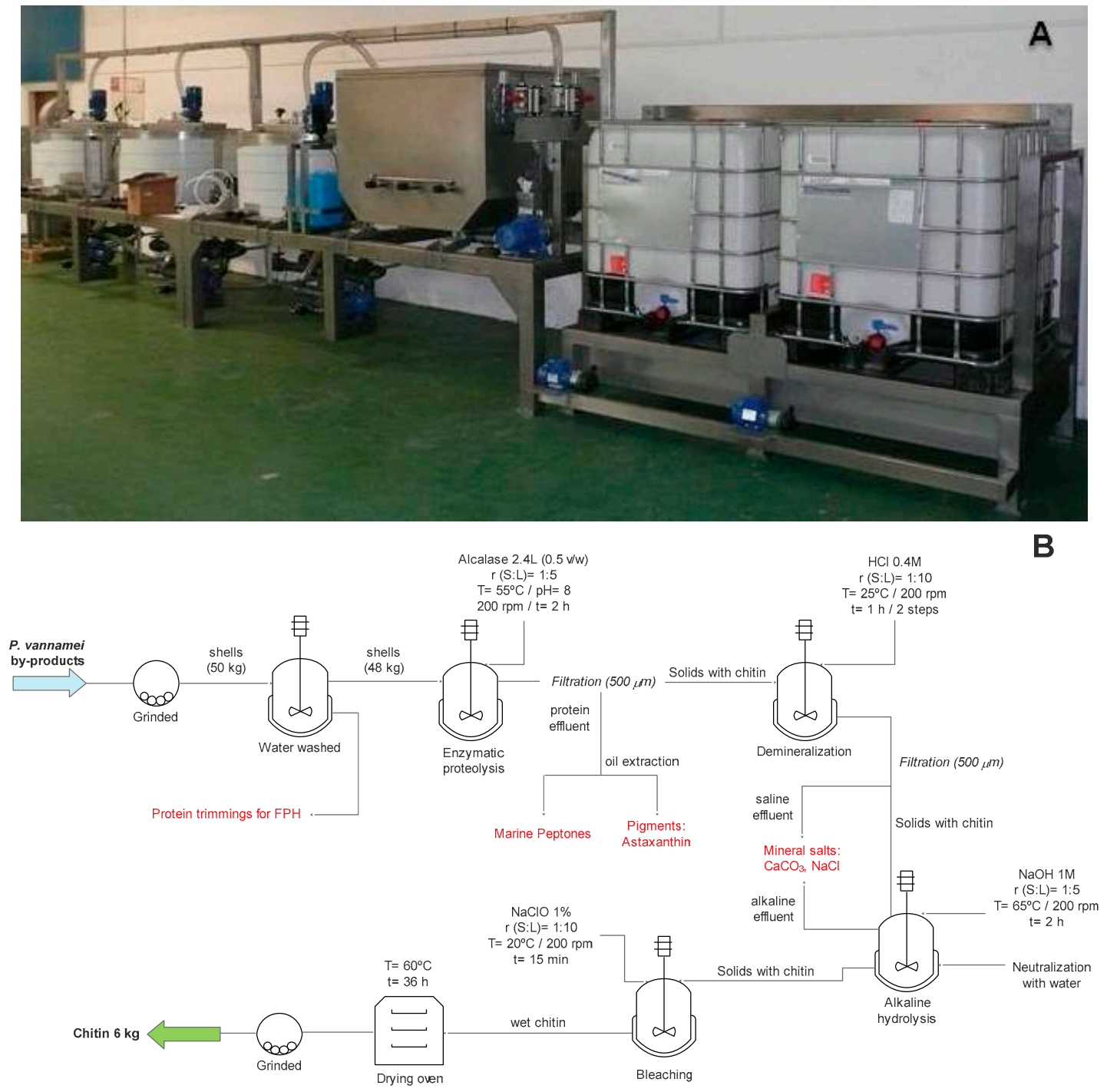

Figure 1. Photograph of the pilot plan developed for the present study (A); Flowchart of chitin production at pilot plan scale combining enzymatic and chemical steps (B).

The results from the elemental analysis-including heavy metals-are also summarized in Table 1. The low values obtained agree with the low ash content in the final chitin samples. $\mathrm{The} \mathrm{Pb}, \mathrm{Hg}$, and $\mathrm{Cd}$ levels are consistent with data previously reported [37], and comply with the values established by European Union legislation [38].

Leaving aside unclear patent references, this is the first approach to the scaled-up production of chitin from waste generated in the industrial processing of P. vannamei (Figure 1A). Additionally, the effluents generated in the process can either represent inputs for other valorization processes, or be safely discarded (Figure 1B). The first effluent and secondary by-product consists of the protein trimmings obtained in the initial water washings, which could be an interesting substrate, after filtration, for the production of fish protein hydrolysates (FPH). Its high protein content (more than $60 \%$ ) and the presence of essential amino acids make this waste a candidate to be enzymatically processed to be applied as a high quality nutrient in aquaculture feed [39-41]. 


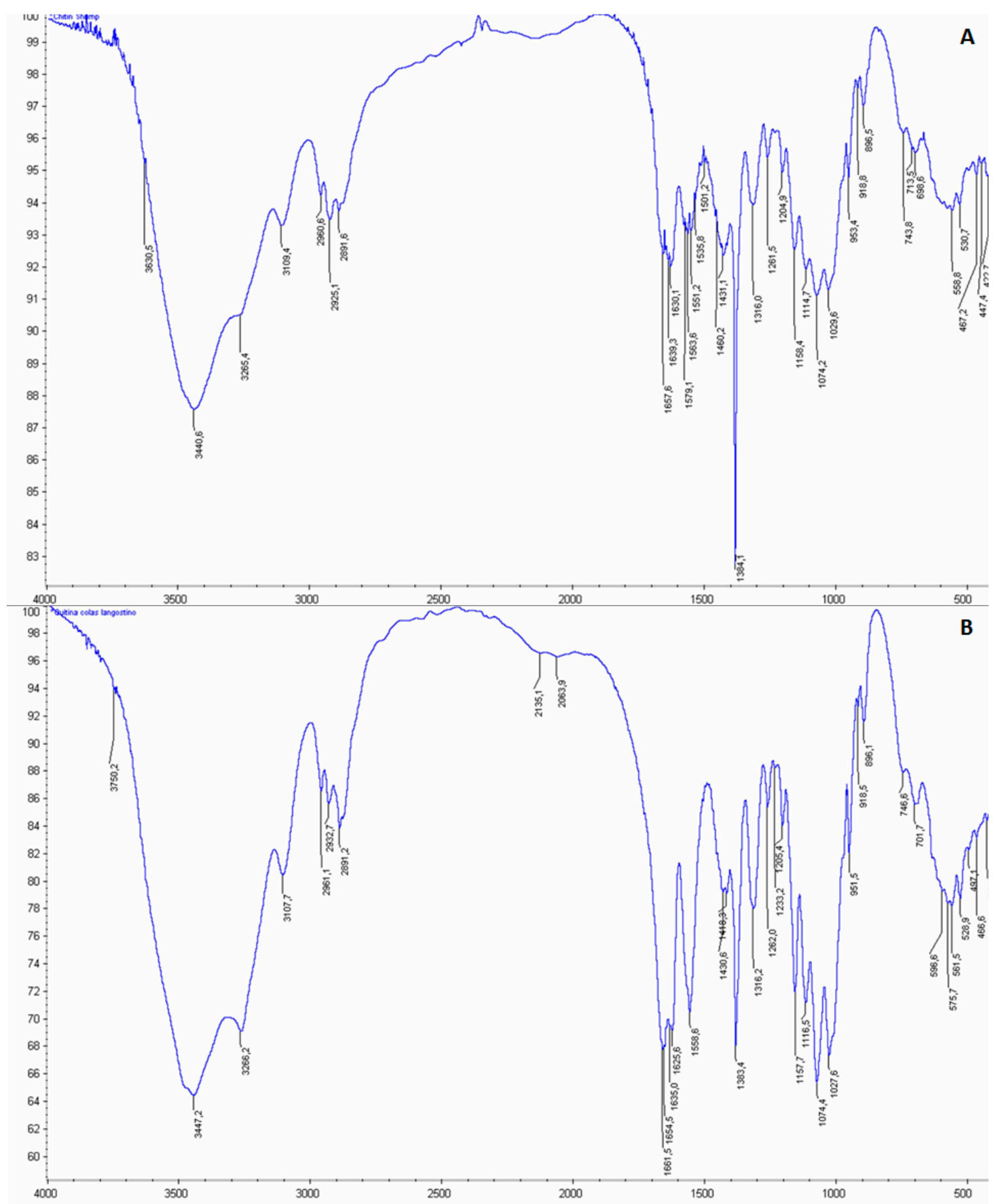

Figure 2. Infrared (IR) spectrum of chitin pattern provided by Sigma-Aldrich (A); IR spectrum of chitin from $P$. vannamei by-products (B).

Subsequent to the enzyme proteolysis of shells and hydrolysate filtration, two fractions are recovered: (a) solids containing chitin, mineral salts, pigments, and remaining protein, later used as a substrate for chitosan production; (b) an effluent rich in soluble proteins and pigments, which can be processed with vegetal oil for the recovery of pigments—-mainly astaxanthin—in the oil fraction [42,43]. The later remaining aqueous fraction contains a remarkable amount of protein $(6.95 \pm 0.22 \mathrm{~g} / \mathrm{L})$, which is possible to separate after centrifugation. Recently, the extraction of pigments from the wastewaters of the industrial processing of P. vannamei shells has been extensively reported [44]. Such approaches are mainly based on vegetal oil extraction at low-medium temperatures $\left(40-70{ }^{\circ} \mathrm{C}\right)$, sometimes combined with previous concentration steps by ultrafiltration membranes and hydrolysis assisted by commercial 
proteases. Regarding the protein effluent, it may be an excellent organic nitrogen source (marine peptones) for the culture of several bacteria (e.g., marine probiotics, lactic acid bacteria, etc.). This was confirmed in a recent study using effluents obtained from the enzymatic $\beta$-chitin production from the pens of Illex argentinus squid [12].

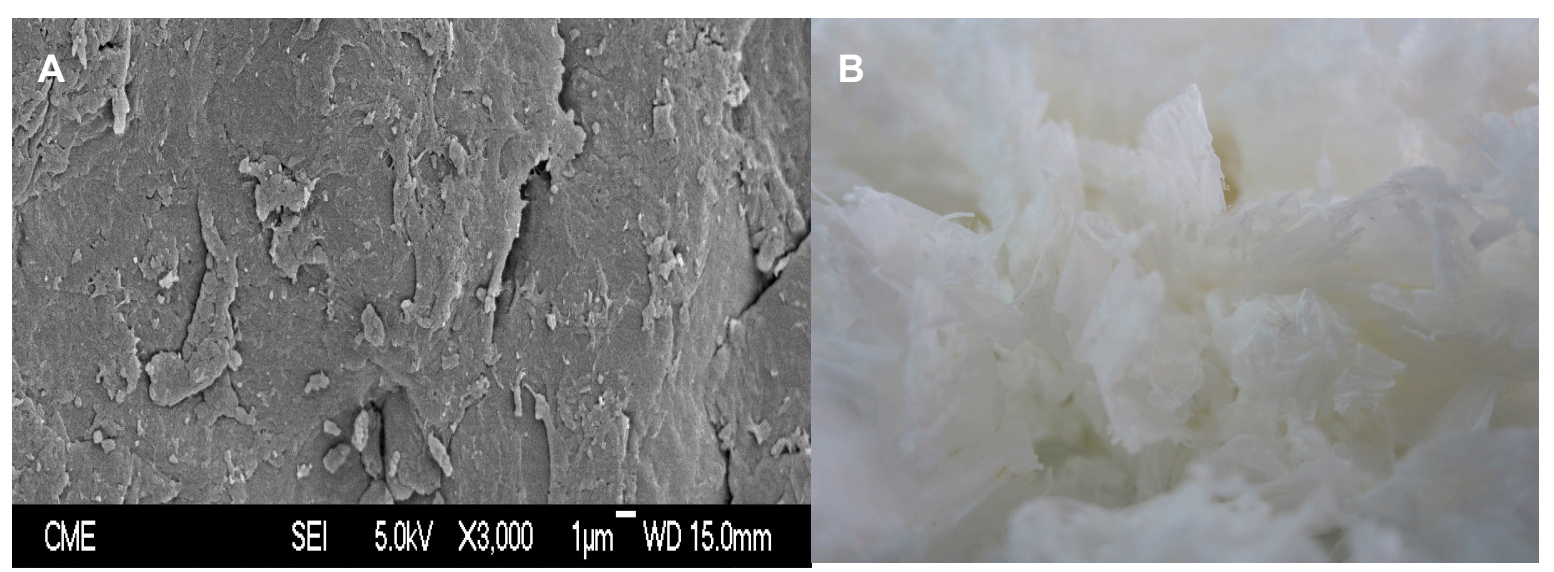

Figure 3. Image of SEM of chitin (A) and normal pictures of white flakes of purified chitin (B).

The effluents from acid demineralization and alkaline hydrolysis are mixed to achieve neutral $\mathrm{pH}$, reducing thereby the difficulty and the cost of managing strong acid and alkaline solutions. Furthermore, this effluent is a good source of calcium (in carbonate and phosphate forms) and sodium (as chloride), which are of increasing interest as food supplements of marine origin $[45,46]$. Finally, the bleaching solution, with a slight orange coloration, can be discharged (or employed for washing the pilot plant) without previous depuration.

\subsection{Optimization of Chitosan Production}

The habitual procedure for chitin deacetylation is mediated by the alkaline hydrolysis of the acetyl groups at high temperature. Although it is not a particularly environmentally friendly process, enzymatic alternatives using deacetylases are not a realistic option nowadays, since no commercial deacetylases are available. Recent studies of fermentative deacetylation using fungus, such as Mucor rouxii, have shown promising results, but crystalline chitin must be necessarily pretreated prior to enzyme hydrolysis to improve the accessibility of the enzyme to the acetyl groups [47]. The applications of the mentioned deacetylases, directly or by fungus fermentation, are not yet used at an industrial scale.

In the present work, a two-factor rotatable design has been performed to study the effect of two independent variables (time and alkali concentration) in the maximization of chitosan production from chitin of P. vannamei waste (Table 2). The main response evaluated is the degree of deacetylation (DD) quantified by Proton Nuclear Magnetic Resonance $\left({ }^{1} \mathrm{H}\right.$-NMR). In this context, ${ }^{1} \mathrm{H}-\mathrm{NMR}$ spectroscopy is the technique employed to determine the structural composition and purity of the polysaccharide (chitosan), based on the intensities of the ${ }^{1} \mathrm{H}$ absorption peaks of the corresponding chitosan chemical shifts (in ppm), with the residual HOD solvent signal as reference. Two examples from the factorial design are depicted in Figure 4. For a highly deacetylated sample (left) obtained after reaction with $50 \% \mathrm{NaOH}$ for $24 \mathrm{~h}$, the ${ }^{1} \mathrm{H}-\mathrm{NMR}$ spectrum shows the common peaks of $\mathrm{N}$-acetyl at $2.09 \mathrm{ppm}$ and $\mathrm{H} 2$ of glucosamine $(\mathrm{GlcN})$ at $3.20 \mathrm{ppm}$. The unresolved signals for protons $\mathrm{H} 2-\mathrm{H} 6$ of $\mathrm{N}$-acetylglucosamine (GlcNAc) and $\mathrm{H} 3-\mathrm{H} 6$ of GlcN appear in the region 3.5-4.0 ppm. The signal of $\mathrm{AcOH}$, tipically seen at $2.11 \mathrm{ppm}$ is absent, indicating very little hydrolysis in the dissolved samples. Similar profiles were observed for chitosan produced under other experimental conditions, such as $12.5 \mathrm{~h} / 50 \% \mathrm{NaOH}$ (spectra not shown). In these cases, DD values are determined from the relative integrals of acetyl ( $\mathrm{N}$-acetyl and $\mathrm{AcOH}$ ) and combined $\mathrm{H} 2-\mathrm{H} 6$ protons of, GlcN and GlcNAc [48,49]. 

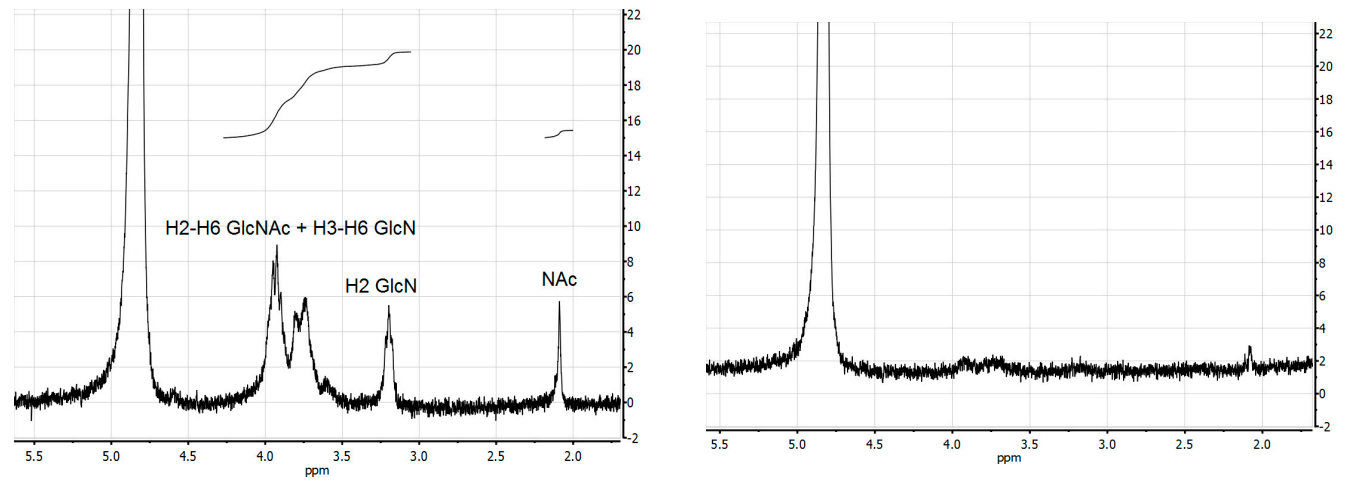

Figure 4. ${ }^{1} \mathrm{H}-\mathrm{NMR}$ spectra for chitosan with high $D D$ obtained in the experimental condition $t=24 \mathrm{~h} / \mathrm{NaOH}=50 \%$ (left) and low DD obtained in the experimental condition $t=20.6 \mathrm{~h} / \mathrm{NaOH}$ $=35.9 \%$ (right). GlcNAc: N-acetylglucosamine, GlcN: glucosamine, NAc: N-acetyl.

In the spectrum on the right, obtained at $20.6 \mathrm{~h} / 35.9 \% \mathrm{NaOH}$, the picture is quite different. The typical signals for chitosan described above show very low intensities, corresponding to also low quantities of chitosan in solution. This indicates that only minute amounts of chitin were converted to chitosan, probably because the conditions applied were too mild to render the material soluble, remaining for the most part as chitin. In this context, the weakness of the signals do not allow to calculate values for $D D$, so in these cases the equation proposed by Ottøy et al. [50] is used instead.

The $D D$ values obtained by both methods are fitted by the polynomial model (2), followed by a statistical analysis using response surface methodology (Table 2).

Table 2. Results of the rotatable second-order design of the combined effect of time $(t)$ and alkali concentration $(\mathrm{NaOH})$ on the production of chitosan (as degree of deacetylation) according to Equation (3) and statistical analysis of significance of the proposed model. The natural values of experimental conditions and the corresponding units are in brackets.

\begin{tabular}{|c|c|c|c|c|c|c|c|}
\hline$t$ & $\mathrm{NaOH}$ & & $D D(\%)$ & $D D_{p}(\%)$ & Coefficients & $t$-Student & Equation \\
\hline$-1(4.4 \mathrm{~h})$ & $-1(35.9 \%)$ & & 54.0 & 44.0 & 87.37 & 50.79 & 87.37 \\
\hline $1(20.6 \mathrm{~h})$ & $-1(35.9 \%)$ & & 19.0 & 28.9 & 12.69 & 9.32 & $12.69 t$ \\
\hline$-1(4.4 \mathrm{~h})$ & $1(64.1 \%)$ & & 33.0 & 12.6 & 4.54 & 3.33 & $4.54 \mathrm{NaOH}$ \\
\hline $1(20.6 \mathrm{~h})$ & $1(64.1 \%)$ & & 79.0 & 78.5 & 20.25 & 10.53 & $20.25 t \mathrm{NaOH}$ \\
\hline$-1.41(1 \mathrm{~h})$ & $0(50 \%)$ & & 21.0 & 40.4 & -14.64 & 9.99 & $-14.64 t^{2}$ \\
\hline $1.41(24 \mathrm{~h})$ & $0(50 \%)$ & & 85.0 & 76.2 & -31.74 & 21.67 & $\begin{array}{c}-31.74 \\
\mathrm{NaOH}^{2}\end{array}$ \\
\hline $0(12.5 \mathrm{~h})$ & $\begin{array}{l}-1.41 \\
(30 \%)\end{array}$ & & 20.0 & 17.9 & - & - & - \\
\hline $0(12.5 \mathrm{~h})$ & $1.41(70 \%)$ & & 18.0 & 30.7 & - & - & - \\
\hline $0(12.5 \mathrm{~h})$ & $0(50 \%)$ & & 92.0 & 87.4 & - & - & - \\
\hline $0(12.5 \mathrm{~h})$ & $0(50 \%)$ & & 83.0 & 87.4 & Average value & 58.92 & - \\
\hline $0(12.5 \mathrm{~h})$ & $0(50 \%)$ & & 84.0 & 87.4 & Expected average value & 87.40 & - \\
\hline $0(12.5 \mathrm{~h})$ & $0(50 \%)$ & & 88.0 & 87.4 & $\operatorname{Var}\left(\mathrm{E}_{\mathrm{e}}\right)$ & 14.8 & - \\
\hline $0(12.5 \mathrm{~h})$ & $0(50 \%)$ & & 90.0 & 87.4 & $t(\alpha<0.05 ; v=4)$ & 2.776 & - \\
\hline & SS & $v$ & $v$ & QM & Mean Square Ratios & \multicolumn{2}{|c|}{ F-Fisher tests } \\
\hline Model (M) & $10,822.8$ & - & 5 & 2164.6 & $\mathrm{QM}_{\mathrm{M}} / \mathrm{QME}=11.73$ & \multicolumn{2}{|c|}{$F_{7}^{5}(\alpha=0.05)=3.972$} \\
\hline Error (E) & 1292.2 & - & 7 & 184.6 & $\mathrm{QM}(\mathrm{M}+\mathrm{LF}) / \mathrm{QM}_{\mathrm{M}}=0.696$ & \multicolumn{2}{|c|}{$F_{5}^{8}(\alpha=0.05)=4.818$} \\
\hline Exp. Error $\left(E_{e}\right)$ & 59.2 & 4 & - & 14.8 & $\mathrm{QM}_{\mathrm{E}} / \mathrm{QM}_{\mathrm{Ee}}=12.47$ & \multicolumn{2}{|c|}{$F_{4}^{7}(\alpha=0.05)=6.094$} \\
\hline Lack of Fit (LF) & 1233.0 & 3 & - & 411.0 & $\mathrm{QM}_{\mathrm{LF}} / \mathrm{QM}_{\mathrm{Ee}}=27.77$ & \multicolumn{2}{|c|}{$F_{4}^{3}(\alpha=0.05)=6.591$} \\
\hline Total & $12,114.9$ & & 12 & - & $R^{2}=0.893$ & - & - \\
\hline 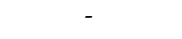 & - & - & - & - & $R_{a d j}^{2}=0.817$ & - & - \\
\hline
\end{tabular}

$D D$ : experimental degree of deacetylation; $D D_{p}$ : predicted degree of deacetylation; NS: non-significant coefficient; SS: sum of squares; v: degrees of freedom; QM: quadratic means of model (M), total error (E), experimental error $\left(\mathrm{E}_{\mathrm{e}}\right)$ and lack of fit (LF). Independent variables according to Table 3. 
Table 3. Experimental domain and codification of independent variables in the factorial rotatable design for chitin deacetylation.

\begin{tabular}{ccc}
\hline \multirow{2}{*}{ Coded Values } & \multicolumn{2}{c}{ Natural Values } \\
\cline { 2 - 3 } & NaOH (\%) & $\boldsymbol{t}(\mathbf{h})$ \\
\hline-1.41 & 30 & 1 \\
-1 & 35.9 & 4.4 \\
0 & 50 & 12.5 \\
+1 & 64.1 & 20.6 \\
+1.41 & 70 & 24 \\
\hline Codification: $V_{c}=\left(V_{n}-V_{0}\right) / \Delta V_{n}$ & \\
Decodification: $V_{n}=V_{0}+\left(\Delta V_{n} \times V_{c}\right)$ & \\
$V_{0}=$ natural value in the centre of the domain \\
$V_{n}=$ natural value of the variable to codify \\
$V_{c}=$ codified value of the variable \\
$\Delta V_{n}=$ increment of $V_{n}$ for unit of $V_{c}$ \\
\hline
\end{tabular}

The outcomes of the multivariate analysis indicate that the statistical signification of coefficients, evaluated by a Student $t$-test ( $\alpha=0.05$ ), is only relevant for the quadratic term of the $\mathrm{NaOH}$ and the joint effect of time and alkali. The value of the coefficient of determination adjusted is remarkable $\left(R_{a d j}^{2}=0.817\right)$, revealing a good correlation between experimental and predicted data, and indicating that the variability of the $D D$ is explained satisfactorily by the second order equation (Table 2). The four F-Fisher tests evaluated are significant, confirming the robustness of the polynomial equation (2).

$$
D D=87.37+12.69 t+4.54 \mathrm{NaOH}+20.25 t \mathrm{NaOH}-14.64 t^{2}-31.74 \mathrm{NaOH}^{2}
$$

Figure 5 displays the experimental data of the $D D$, and the predicted surfaces generated by the model. Based on this equation, the optimal conditions calculated by numerical derivation $[51,52]$ are $\mathrm{NaOH}=53.8 \%$ and $t=17.5 \mathrm{~h}$. The degree of deacetylation calculated in these values is $92 \%$.

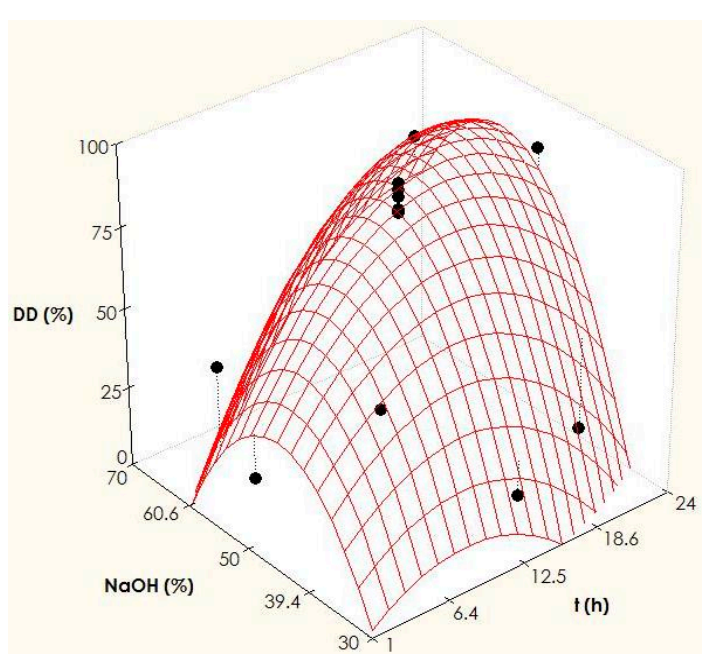

Figure 5. Experimental data (points) and theoretical response surfaces describing the joint effects of alkali and processing time on chitosan production from P. vannamei chitin.

The molecular weights $(\mathrm{Mw})$ of various samples from the previous factorial design were also determined, by gel permeation chromatography (GPC). The values of the Mws are different depending on the experimental conditions applied, ranging from 58 to $82 \mathrm{kDa}$ for the more deacetylated samples to $91-93 \mathrm{kDa}$ for the acetylated ones (basically non-deacetylated chitin). 
Higher Mw chitosan (150 kDa) has been obtained working at higher temperatures and lower $\mathrm{NaOH}$ concentrations using the shrimp wastes of non-defined species [52]. A structural analysis by SEM was also performed in four samples (Figure 6). The top images (A and B) also showed irregular patterns, with the presence of microfibrils indicating a perfect crystal structure as a result of a regular packing of the chains corresponding to chitin. In fact, when comparing these images with the obtained crystallinity index ( $86 \%$ and $85 \%)$ and the values of the $D D(20 \%$ and $19 \%)$, it is evident that they are chitin. In the bottom images (C and D), less crystallinity was observed, in agreement with the data of the $D D(84 \%$ and $85 \%$, respectively).

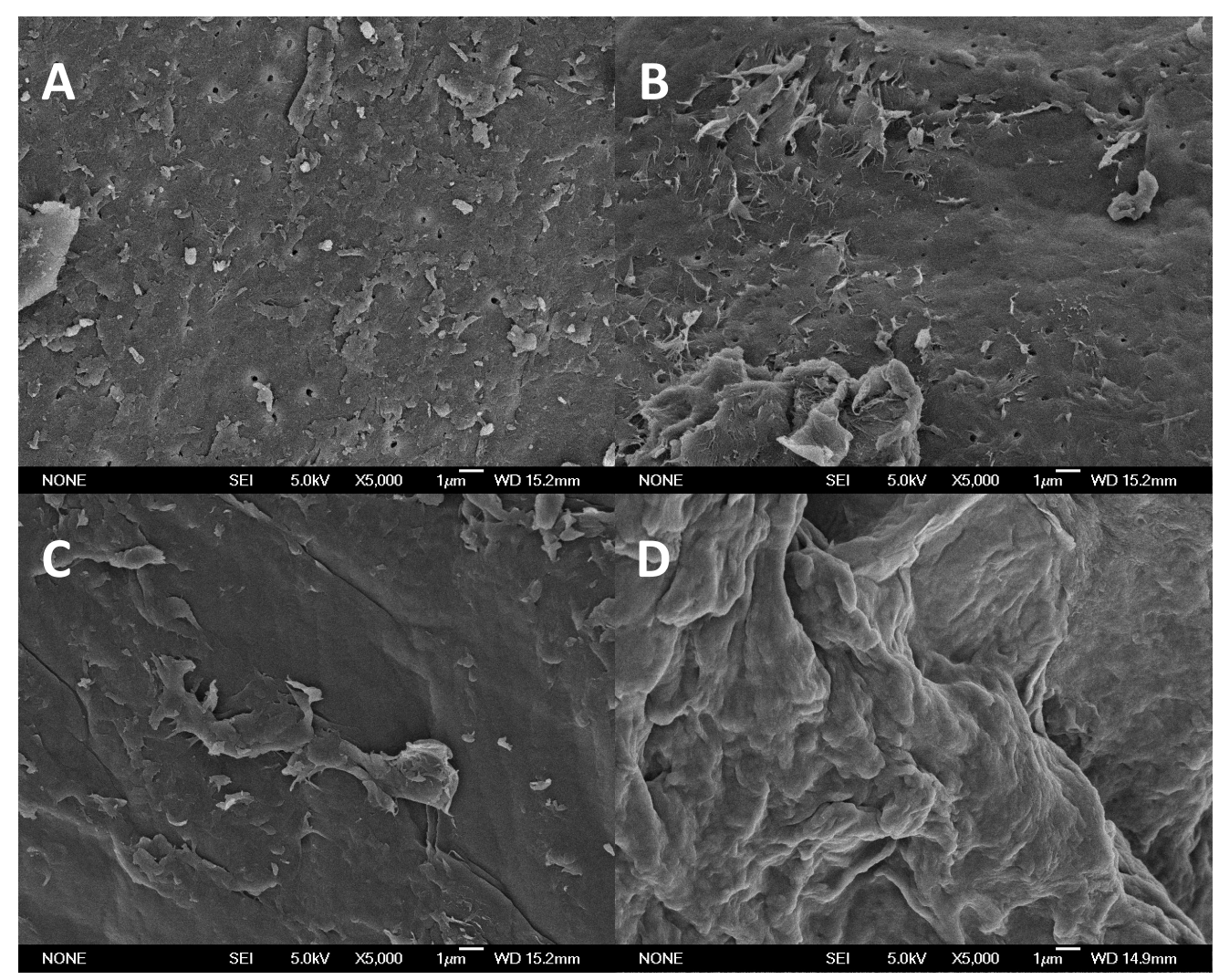

Figure 6. Images of SEM for chitin (A,B) and chitosan (C,D) samples obtained at different experimental conditions. (A) $12.5 \mathrm{~h} / \mathrm{NaOH} 30 \%$; (B) $20.6 \mathrm{~h} / \mathrm{NaOH} 35.9 \%$; (C) $12.5 \mathrm{~h} / \mathrm{NaOH} 50 \%$ and (D) $24 \mathrm{~h} / \mathrm{NaOH} 50 \%$.

\section{Experimental Section}

\subsection{Raw Materials and Extraction of Chitin}

The shrimp (Penaeus vannamei) by-products, mainly exoskeleton of cephalothorax, were kindly provided by Pescanova S.A. (Vigo, Spain) and stored at $-20{ }^{\circ} \mathrm{C}$ until use. The purification of the chitin was performed in a pilot plant built for this purpose by Grupo Josmar S.L. (Pontevedra, Spain). This plant consists of three conical stainless steel reactors (each one $500 \mathrm{~L}$ ), fully equipped with controllers of $\mathrm{pH}$, temperature, and agitation as well as auxiliary equipment (transfer pumps, membrane filters, spray-dryer, etc.) designed for the main treatment of crustacean by-products to produce chitin (Figure 1, top): (a) enzymatic proteolysis (by Alcalase); (b) acid demineralization (by $\mathrm{HCl}$ ); and (c) alkaline hydrolysis (using $\mathrm{NaOH}$ ) and chemical bleaching (by $\mathrm{NaClO}$ ). The commercial chitin from shrimp shells (reference C7170) was purchased from Sigma-Aldrich SA (St. Louis, MO, USA). 
The chitin production line was performed (in duplicate) using batches of $50 \mathrm{~kg}$ of shrimp by-products (Figure 1, bottom). Initially, these materials were ground $(0.5-1.5 \mathrm{~cm})$ and washed to eliminate protein trimmings from the rest of the crustacean's body. Subsequently, the shrimp exoskeleton was hydrolysed by a commercial protease, Alcalase 2.4L (Novozymes S.A.), at an enzyme concentration of $0.5\left(v / w\right.$ of substrate) in a solid:liquid ratio of $1: 5(w / v)$ with distilled water at $55^{\circ} \mathrm{C}$ and $\mathrm{pH}=8$. A constant $\mathrm{pH}$ was maintained for $2 \mathrm{~h}$ by the addition of $1 \mathrm{M} \mathrm{NaOH}$ as required. At the end of the enzyme proteolysis, the solids were separated from the protein effluent by filtration $(500 \mu \mathrm{m})$, and passed on to the next step: acid treatment with $0.4 \mathrm{M} \mathrm{HCl}$ using solid:liquid ratio of 1:10 $(w / v)$ for $1 \mathrm{~h}$ under agitation (200 rpm) at room temperature. This second stainless steel reactor is internally covered with an epoxy material to prevent a strong acid attack. After the acid treatment, the effluent was filtered and the solid was washed until neutral $\mathrm{pH}$. The acid treatment was performed twice. The last stage was an alkaline treatment with $\mathrm{NaOH} 1 \mathrm{M}$ using a ratio $1: 5(w / v)$ for $2 \mathrm{~h}$ at $65^{\circ} \mathrm{C}$, then the solid was washed to neutrality and treated with $1 \%$ sodium hypochlorite (ratio 1:10 w/v) for $15 \mathrm{~min}$ at room temperature. Finally, the solution was filtered and the resulting solids (chitin) were dried (by drying oven) at $60^{\circ} \mathrm{C}$ for $24 \mathrm{~h}$ and milled.

\subsection{Compositional Characterization of P. vannamei By-Products and Produced Chitin}

Different methods were applied to characterize both the shrimp cephalotorax and the purified chitin: the water content was determined by drying at $105^{\circ} \mathrm{C}$ until constant weight; the total nitrogen was analyzed according to the Kjeldahl procedure [53]; the ash content was assessed according to the AOAC protocol [53]; and all of the lipids were extracted by the Bligh and Dyer method [54].

In chitin, the presence of ions was quantified by inductively coupled plasma mass spectrometry (ICP-MS), and the heavy metal content by atomic absorption spectroscopy (AAS). The IR measurements were performed at room temperature on a Thermo Nicolet 6700 FTIR infrared spectrometer. The samples were prepared in a $\mathrm{KBr}$ pellet at a ratio sample/ $\mathrm{KBr}$ of 1:10, and measured in transmission mode in the 400 to $4000 \mathrm{~cm}^{-1}$ range using a DTGS type detector (deuterated triglycerin sulfate) and a divider of $\mathrm{KBr}$ beam. The $\mathrm{C} / \mathrm{N}$ ratio was determined by combustion at $1200{ }^{\circ} \mathrm{C}$ in a $\mathrm{LECO}$ $\mathrm{CN}-2000$ analyzer.

\subsection{Experimental Design for the Production of Chitosan and Statistical Analysis}

A second order rotatable design with quintuple replication in the centre of the experimental domain was performed [55], in order to maximize the deacetylation of the chitin to produce chitosan (Table 1). The combined effect of $\mathrm{NaOH}$ (in \%) and the time of hydrolysis ( $t$, in h) on chitosan production was studied, using as dependent variables (responses) the degree of deacetylation $(D D)$ and the solubility $(S)$ in acetic acid of the resulting solids. The experimental conditions varied between 1 and $24 \mathrm{~h}$ for $t$ and $30-70 \%$ for $\mathrm{NaOH}$; the solid:liquid ratio $(1: 20)$ and temperature $\left(90{ }^{\circ} \mathrm{C}\right)$ were kept constant. The experimental units were $300 \mathrm{~mL}$ Erlenmeyer flasks with $5 \mathrm{~g}$ of chitin and $100 \mathrm{~mL}$ of $\mathrm{NaOH}$ solution, each unit fully sampled at the established time intervals. The samples were centrifuged, the supernatant stored at $-20^{\circ} \mathrm{C}$, and the solid dried at $60^{\circ} \mathrm{C}$ for $24 \mathrm{~h}$ and stored in sealed bags for further characterization.

The experimental results of the factorial designs were modelled by second-order polynomial equations, as:

$$
Y=b_{0}+\sum_{i=1}^{n} b_{i} X_{i}+\sum_{\substack{i=1 \\ j>i}}^{n-1} \sum_{j=2}^{n} b_{i j} X_{i} X_{j}+\sum_{i=1}^{n} b_{i i} X_{i}^{2}
$$

where $Y$ represents the response to be modelled; $b_{0}$ is the constant coefficient, $b_{i}$ is the coefficient of linear effect; $b_{i j}$ is the coefficient of interaction effect; $b_{i i}$ the coefficients of squared effect; $n$ is the number of variables; and $X_{i}$ and $X_{j}$ define the independent variables. 
The goodness-of-fit was established as the adjusted determination coefficient $\left(R_{a d j}^{2}\right)$, the statistical significance of the coefficients was verified by means of the Student $t$-test $(\alpha=0.05)$, and the model consistency by the Fisher $F$ test $(\alpha=0.05)$, using the following mean squares ratios:

$$
\begin{aligned}
& \quad \text { Mean Squares Ratios } \\
& F 1=\text { Model } / \text { Total error } \\
& F 2=(\text { Model }+ \text { Lack of fitting }) / \text { Model } \\
& F 3=\text { Total error } / \text { Experimental error } \\
& F 4=\text { Lack of fitting } / \text { Experimental error }
\end{aligned}
$$

\section{the Model Is Acceptable When}

$$
\begin{aligned}
& F 1 \geq F_{d e n}^{\text {num }} \\
& F 2 \leq F_{\text {den }}^{\text {num }} \\
& F 3 \leq F_{\text {den }}^{\text {num }} \\
& F 4 \leq F_{\text {den }}^{\text {num }}
\end{aligned}
$$

$F_{d e n}^{\text {num }}$ are the theoretical values to $\alpha=0.05$ with the corresponding degrees of freedom for the numerator (num) and denominator (den). All of the fitting procedures, coefficient estimates, and statistical calculations were performed on a Microsoft Excel spreadsheet and confirmed by Statistica 8.0 (StatSoft, Inc., Palo Alto, CA, USA, 2001).

\subsection{Chemical and Structural Characterization of Chitin and Chitosan}

Scanning Electron Microscopy (SEM) images were obtained on a JEOL JSM-6400 microscope (Westmont, IL, USA), with acceleration voltage of up to $40 \mathrm{kV}$ and resolution of $36 \AA$. The samples were prepared on a metal slide with a double-sided adhesive sticker, and covered with a thin layer of gold.

Crystallinity (DRX) was assessed with a PHILIPS X'PERT MPD automatic diffractometer (Almelo, The Netherlands), equipped with a goniometer PW3050 $(\theta-2 \theta)$, at a generator power of $45 \mathrm{kV}$ and $40 \mathrm{~mA}$. The measurements were made at room temperature with $\mathrm{Cu} \mathrm{K} \alpha 1$ radiation (wavelength $1.54056 \AA$ ) , with a graphite monochromator and confocalised geometry (Bragg-Brentano). The step size $(2 \theta)$ of the measurements was set at $0.040^{\circ}$, and the duration of the step at $1 \mathrm{~s}$. The angular range studied was $5^{\circ}$ to $40^{\circ} 2 \theta$. The percentage of crystalline material in chitin is expressed by a crystallinity index (ICr), determined according to the method proposed by Segal [36].

The deacetylation degree $(D D)$ was determined by Proton Nuclear Magnetic Resonance ( $\left.{ }^{1} \mathrm{H}-\mathrm{NMR}\right)$ performed at room temperature on a Bruker Avance II spectrometer (Billerica, MA, USA) at a resonance frequency of $400 \mathrm{MHz}$. Mestrenova 10.0 software (Mestrelab Research, Santiago de Compostela, Spain) was used for spectral processing. Chitosan samples were dissolved in $0.056 \mathrm{M}$ deuterated trifluoroacetic acid (TFA-d in $\mathrm{D}_{2} \mathrm{O}$ ) at a concentration of $7 \mathrm{~g} / \mathrm{L}$.

The molecular weight $(\mathrm{Mw})$ was measured by gel permeation chromatography (GPC). The chromatographic system consists of a Waters 625 LC System pump connected to an Ultrahydrogel column $\left(300 \times 7.8 \mathrm{~mm}\right.$, Waters, Milford, MA, USA), thermostated in an oven at $35^{\circ} \mathrm{C}$. The detectors were refractive index (Waters 2414), coupled in line with Evaporative Light Scattering (ELS Waters 2424). The mobile phase was $0.2 \mathrm{M} \mathrm{CH}_{3} \mathrm{COOH} / 0.15 \mathrm{M} \mathrm{CH}_{3} \mathrm{COONH}_{4}$ working under a flow rate of $0.5 \mathrm{~mL} / \mathrm{min}$ and an injection volume of $20 \mu \mathrm{L}$. The chitosan samples were prepared at a concentration of $1 \mathrm{mg} / \mathrm{mL}$ in the same mobile phase solution. All of the solvents and solutions were filtered through $0.45 \mu \mathrm{m}$ filters (Millipore, Billerica, MA, USA). The standard samples of chitosan were used to establish the molecular weight average of the analyzed samples.

\section{Conclusions}

The pilot plant production of chitin from P. vannamei by-products (cephalotorax shells) by a combination of enzymatic and chemical processes was performed. The characteristics of the chitin obtained were: $96 \%$ of acetylation degree; $88 \%$ of crystallinity; and a very low content of ashes, lipids, proteins, and heavy metals (trace in some cases). Using the response surface methodology, the joint effect of time and $\mathrm{NaOH}$ concentration were also studied. The optimal conditions of the deacetylation reaction were obtained at $53.8 \%$ of $\mathrm{NaOH}$ and $17.5 \mathrm{~h}$ of processing in order to produce chitosan with a $D D$ of $92 \%$ and $\mathrm{Mw}$ of $82 \mathrm{kDa}$. This methodology and the predictive polynomial equation developed 
can be used for the production of chitosan with defined DD values. Further studies performing RSM should be done to produce chitosan from $P$. vannamei with tailored molecular weights.

Acknowledgments: This research was funded by means of a contract with Pescanova S.A. (CSIC-code 070401090017). SEM and GPC analysis were performed by InFiQus S.L. (Tres Cantos, Madrid, Spain). NMR, IR and $\mathrm{C} / \mathrm{N}$ were measured in CACTI-University of Vigo.

Author Contributions: J.A.V. designed the experiments, developed the mathematical models and wrote the manuscript. P.R. performed the experiments and helped in the manuscript preparation. J.M. worked in the experiments carried out. J.V. helped in the characterization of chitosans. C.G.S supervised the experiments. R.I.P.M. designed the pilot plant and performed the pilot plant experiments and has been in the critical reading of the manuscript. All authors read and approved the manuscript.

Conflicts of Interest: The authors declare no conflict of interest.

\section{References}

1. Food and Agriculture (FAO). The State of World Fisheries and Aquaculture. Contributing to Food Security and Nutrition for All; FAO: Rome, Italy, 2016; p. 200. ISBN 978-92-5-109185-2. Available online: http:/ / www.fao.org/3/a-i5555e.pdf (accessed on 21 April 2017).

2. Kumar, M.N.R. A review of chitin and chitosan applications. React. Funct. Polym. 2000, 46, 1-27. [CrossRef]

3. Jayakumar, R.; Prabaharan, M.; Kumar, P.S.; Nair, S.; Tamura, H. Biomaterials based on chitin and chitosan in wound dressing applications. Biotechnol. Adv. 2011, 29, 322-337. [CrossRef] [PubMed]

4. Ferhat, M.; Kadouche, S.; Drouiche, N.; Messaoudi, K.; Messaoudi, B.; Lounici, H. Competitive adsorption of toxic metals on bentonite and use of chitosan as flocculent coagulant to speed up the settling of generated clay suspensions. Chemosphere 2016, 165, 87-93. [CrossRef] [PubMed]

5. Bouhenna, M.; Salah, R.; Bakour, R.; Drouiche, N.; Abdi, N.; Grib, H.; Lounici, H.; Mameri, N. Effects of chitin and its derivatives on human cancer cells lines. Environ. Sci. Pollut. Res. 2015, 22, 15579-15586. [CrossRef] [PubMed]

6. Shahidi, F.; Arachchi, J.K.V.; Jeon, Y.-J. Food applications of chitin and chitosans. Trends Food Sci. Technol. 1999, 10, 37-51. [CrossRef]

7. Jeon, Y.-J.; Shahidi, F.; Kim, S.-K. Preparation of chitin and chitosan oligomers and their applications in physiological functional foods. Food Rev. Int. 2000, 16, 159-176. [CrossRef]

8. Tharanathan, R.N.; Kittur, F.S. Chitin-The undisputed biomolecule of great potential. Crit. Rev. Food Sci. Nutr. 2003, 43, 61-87. [CrossRef] [PubMed]

9. Tolaimate, A.; Desbrieres, J.; Rhazi, M.; Alagui, A. Contribution to the preparation of chitins and chitosans with controlled physico-chemical properties. Polymer 2003, 44, 7939-7952. [CrossRef]

10. Synowiecki, J.; Al-Khateeb, N.A. Production, properties, and some new applications of chitin and its derivatives. Crit. Rev. Food Sci. Nutr. 2003, 43, 145-171. [CrossRef] [PubMed]

11. Benhabiles, M.; Salah, R.; Lounici, H.; Drouiche, N.; Goosen, M.; Mameri, N. Antibacterial activity of chitin, chitosan and its oligomers prepared from shrimp shell waste. Food Hydrocoll. 2012, 29, 48-56. [CrossRef]

12. Vázquez, J.A.; Caprioni, R.; Nogueira, M.; Menduiña, A.; Ramos, P.; Pérez-Martín, R.I. Valorisation of effluents obtained from chemical and enzymatic chitin production of Illex argentinus pen by-products as nutrient supplements for various bacterial fermentations. Biochem. Eng. J. 2016, 116, 34-44. [CrossRef]

13. Benhabiles, M.S.; Abdi, N.; Drouiche, N.; Lounici, H.; Pauss, A.; Goosen, M.F.A.; Mameri, N. Protein recovery by ultrafiltration during isolation of chitin from shrimp shells Parapenaeus longirostris. Food Hydrocoll. 2013, 32, 28-34. [CrossRef]

14. Gildberg, A.; Stenberg, E. A new process for advanced utilisation of shrimp waste. Process Biochem. 2001, 36, 809-812. [CrossRef]

15. Arancibia, M.Y.; Alemán, A.; Calvo, M.M.; López-Caballero, M.E.; Montero, P.; Gómez-Guillén, M.C. Antimicrobial and antioxidant chitosan solutions enriched with active shrimp (Litopenaeus vannamei) waste materials. Food Hydrocoll. 2014, 35, 710-717. [CrossRef]

16. Kurita, K.; Akao, H.; Yang, J.; Shimojoh, M. Nonnatural branched polysaccharides: Synthesis and properties of chitin and chitosan having disaccharide maltose branches. Biomacromolecules 2003, 4, 1264-1268. [CrossRef] [PubMed] 
17. Younes, I.; Ghorbel-Bellaaj, O.; Nasri, R.; Chaabouni, M.; Rinaudo, M.; Nasri, M. Chitin and chitosan preparation from shrimp shells using optimized enzymatic deproteinization. Process Biochem. 2012, 47, 2032-2039. [CrossRef]

18. Vázquez, J.A.; Rodríguez-Amado, I.; Montemayor, M.I.; Fraguas, J.; González, M.d.P.; Murado, M.A. Chondroitin sulfate, hyaluronic acid and chitin/chitosan production using marine waste sources: Characteristics, applications and eco-friendly processes: A review. Mar. Drugs 2013, 11, 747-774. [CrossRef] [PubMed]

19. Majekodunmi, S.O. Current development of extraction, characterization and evaluation of properties of chitosan and its use in medicine and pharmaceutical industry. Am. J. Polym. Sci. 2016, 6, 86-91.

20. Duan, S.; Li, L.; Zhuang, Z.; Wu, W.; Hong, S.; Zhou, J. Improved production of chitin from shrimp waste by fermentation with epiphytic lactic acid bacteria. Carbohydr. Polym. 2012, 89, 1283-1288. [CrossRef] [PubMed]

21. Jung, W.; Jo, G.; Kuk, J.; Kim, Y.; Oh, K.; Park, R. Production of chitin from red crab shell waste by successive fermentation with Lactobacillus paracasei kctc-3074 and serratia marcescens fs-3. Carbohydr. Polym. 2007, 68, 746-750. [CrossRef]

22. Younes, I.; Ghorbel-Bellaaj, O.; Chaabouni, M.; Rinaudo, M.; Souard, F.; Vanhaverbeke, C.; Jellouli, K.; Nasri, M. Use of a fractional factorial design to study the effects of experimental factors on the chitin deacetylation. Int. J. Biol. Macromol. 2014, 70, 385-390. [CrossRef] [PubMed]

23. Younes, I.; Hajji, S.; Rinaudo, M.; Chaabouni, M.; Jellouli, K.; Nasri, M. Optimization of proteins and minerals removal from shrimp shells to produce highly acetylated chitin. Int. J. Biol. Macromol. 2016, 84, $246-253$. [CrossRef] [PubMed]

24. Jiang, Q.-H.; Ye, S.-Q.; Wang, Y. Optimization of the preparation of chitosan from wastes of Penaeus vannamei. Mod. Food Sci. Technol. 2013, 2, 023.

25. Demim, S.; Drouiche, N.; Aouabed, A.; Benayad, T.; Couderchet, M.; Semsari, S. Study of heavy metal removal from heavy metal mixture using the CCD method. J. Ind. Eng. Chem. 2014, 20, 512-520. [CrossRef]

26. Demim, S.; Drouiche, N.; Aouabed, A.; Benayad, T.; Dendene-Badachee, O.; Semsari, S. Cadmium and nickel:Assessment of the physiological effects and heavy metal removal using a response surface approach by L. gibba. Ecol. Eng. 2013, 61, 426-435. [CrossRef]

27. Blanco, M.; Fraguas, J.; Sotelo, C.G.; Pérez-Martín, R.I.; Vázquez, J.A. Production of chondroitin sulphate from head, skeleton and fins of Scyliorhinus canicula by-products by combination of enzymatic, chemical precipitation and ultrafiltration methodologies. Mar. Drugs 2015, 13, 3287-3308. [CrossRef] [PubMed]

28. Gopalakannan, A.; Jasmine, G.I.; Shanmugam, S.; Sugumar, G. Application of proteolytic enzyme, papain for the production of chitin and chitosan from shrimp waste. J. Mar. Biol. Assoc. India 2000, 42, 167-172.

29. Allwin, S.I.J.; Jeyasanta, K.I.; Patterson, J. Extraction of chitosan from white shrimp (Litopenaeus vannamei) processing waste and examination of its bioactive potentials. Adv. Biol. Res. 2015, 9, 389-396.

30. Gagne, N.; Simpson, B. Use of proteolytic enzymes to facilitate the recovery of chitin from shrimp wastes. Food Biotechnol. 1993, 7, 253-263. [CrossRef]

31. Gartner, C.; Peláez, C.A.; López, B.L. Characterization of chitin and chitosan extracted from shrimp shells by two methods. e-Polymers 2010, 10, 748-763. [CrossRef]

32. Dziril, M.; Grib, H.; Laribi-Habchi, H.; Drouiche, N.; Abdi, N.; Lounici, H.; Pauss, A.; Mameri, N. Chitin oligomers and monomers production by coupling $\gamma$ radiation and enzymatic hydrolysis. J. Ind. Eng. Chem. 2015, 26, 396-401. [CrossRef]

33. Xu, J.; McCarthy, S.P.; Gross, R.A.; Kaplan, D.L. Chitosan film acylation and effects on biodegradability. Macromolecules 1996, 29, 3436-3440. [CrossRef]

34. Kasaai, M. A review of several reported procedures to determinate the degree of $N$-acetylation for chitin and chitosan using infrared spectroscopy. Carbohydr. Polym. 2007, 75, 497-508.

35. Cárdenas, G.; Cabrera, G.; Taboada, E.; Miranda, S.P. Chitin characterization by SEM, FTIR, XRD, and 13C cross polarization/mass angle spinning NMR. J. Appl. Polym. Sci. 2004, 93, 1876-1885. [CrossRef]

36. Segal, L.; Creely, J.; Martin, A., Jr.; Conrad, C. An empirical method for estimating the degree of crystallinity of native cellulose using the x-ray diffractometer. Text. Res. J. 1959, 29, 786-794. [CrossRef]

37. Lopes, C.; Antelo, L.T.; Franco-Uría, A.; Alonso, A.A.; Pérez-Martín, R. Chitin production from crustacean biomass: Sustainability assessment of chemical and enzymatic processes. J. Clean. Prod. 2017. [CrossRef] 
38. Commission Regulation (ec) no 629/2008 of 2 July 2008 Amending Regulation (ec) no 1881/2006 Setting Maximum Levels for Certain Contaminants in Foodstuffs. Available online: http:/ / eur-lex.europa.eu/legalcontent/EN/ALL/?uri=CELEX\%3A32008R0629 (accessed on 21 April 2017).

39. Cudennec, B.; Ravallec-Plé, R.; Courois, E.; Fouchereau-Peron, M. Peptides from fish and crustacean by-products hydrolysates stimulate cholecystokinin release in stc-1 cells. Food Chem. 2008, 111, 970-975. [CrossRef]

40. Goosen, N.; de Wet, L.; Görgens, J. Comparison of hydrolysed proteins from different raw materials in diets for mozambique tilapia Oreochromis mossambicus. Aquac. Int. 2015, 23, 1165-1178. [CrossRef]

41. Benhabiles, M.; Abdi, N.; Drouiche, N.; Lounici, H.; Pauss, A.; Goosen, M.; Mameri, N. Fish protein hydrolysate production from sardine solid waste by crude pepsin enzymatic hydrolysis in a bioreactor coupled to an ultrafiltration unit. Mater. Sci. Eng. C 2012, 32, 922-928. [CrossRef]

42. Amado, I.R.; González, M.; Murado, M.A.; Vázquez, J.A. Shrimp wastewater as a source of astaxanthin and bioactive peptides. J. Chem. Technol. Biotechnol. 2016, 91, 793-805. [CrossRef]

43. Amado, I.R.; Vázquez, J.A.; Murado, M.A.; González, M.P. Recovery of astaxanthin from shrimp cooking wastewater: Optimization of astaxanthin extraction by response surface methodology and kinetic studies. Food Bioprocess Technol. 2015, 8, 371-381. [CrossRef]

44. García-López, M.; Pérez-Martín, R.I.; Sotelo, C.G. Carotenoid pigments composition of two commonly discarded decapod crustaceans in grand sole and the Galician-Northern Portugal coast fisheries. J. Aquat. Food Prod. Technol. 2016, 25, 114-121. [CrossRef]

45. Yoon, G.A.; Kim, Y.M.; Chi, G.Y.; Hwang, H.J. Effects of tuna bone and herbal extract on bone metabolism in ovariectomized rats. Nutr. Res. 2005, 25, 1013-1019. [CrossRef]

46. Herpandi, N.H.; Rosma, A.; Wan Nadiah, W. The tuna fishing industry: A new outlook on fish protein hydrolysates. Compr. Rev. Food Sci. Food Saf. 2011, 10, 195-207. [CrossRef]

47. Zhao, Y.; Park, R.-D.; Muzzarelli, R.A. Chitin deacetylases: Properties and applications. Mar. Drugs 2010, 8 , 24-46. [CrossRef] [PubMed]

48. Raymond, L.; Morin, F.G.; Marchessault, R.H. Degree of deacetylation of chitosan using conductometric titration and solid-state nmr. Carbohydr. Res. 1993, 246, 331-336. [CrossRef]

49. Paulino, A.T.; Simionato, J.I.; Garcia, J.C.; Nozaki, J. Characterization of chitosan and chitin produced from silkworm crysalides. Carbohydr. Polym. 2006, 64, 98-103. [CrossRef]

50. Ottøy, M.H.; Vårum, K.M.; Christensen, B.E.; Anthonsen, M.W.; Smidsrød, O. Preparative and analytical size-exclusion chromatography of chitosans. Carbohydr. Polym. 1996, 31, 253-261. [CrossRef]

51. Wardhani, D.H.; Vázquez, J.A.; Pandiella, S.S. Optimisation of antioxidants extraction from soybeans fermented by Aspergillus oryzae. Food Chem. 2010, 118, 731-739. [CrossRef]

52. Weska, R.; Moura, J.M.D.; Batista, L.D.M.; Rizzi, J.; Pinto, L.A.D.A. Optimization of deacetylation in the production of chitosan from shrimp wastes: Use of response surface methodology. J. Food Eng. 2007, 80, 749-753. [CrossRef]

53. Association of Official Analytical Chemists (AOAC). Methods of Analysis, 15th ed.; AOAC: Washington, DC, USA, 1990.

54. Bligh, E.G.; Dyer, W.J. A rapid method of total lipid extraction and purification. Can. J. Biochem. Phys. 1959, 37, 911-917. [CrossRef] [PubMed]

55. Box, G.E.; Hunter, J.S.; Hunter, W.G. Statistics for Experimenters: Design, Innovation, and Discovery; John Wiley \& Sons, Inc.: Hoboken, NJ, USA, 2005.

(C) 2017 by the authors. Licensee MDPI, Basel, Switzerland. This article is an open access article distributed under the terms and conditions of the Creative Commons Attribution (CC BY) license (http://creativecommons.org/licenses/by/4.0/). 